\title{
Unilateral facial nerve palsy as an early presenting symptom of relapse in a paediatric patient with acute lymphoblastic leukaemia
}

\author{
Leslie Y Chiang, ${ }^{1}$ John Ross Crawford, ${ }^{2}$ Dennis John Kuo ${ }^{3}$
}

\begin{abstract}
${ }^{1}$ Department of Pediatrics, University of California, San Diego, La Jolla, California, USA ${ }^{2}$ Department of Neurosciences and Pediatrics, University of California, San Diego, San Diego, California, USA ${ }^{3}$ Department of Pediatric Hematology-Oncology, University of California, San Diego, San Diego, California, USA
\end{abstract}

\section{Correspondence to}

Dr Dennis John Kuo,

dekuo@ucsd.edu

Accepted 25 February 2017
CrossMark

\begin{tabular}{l}
\hline To cite: Chiang LY, \\
Crawford JR, Kuo DJ. BMJ \\
Case Rep Published online: \\
[please include Day Month \\
Year] doi:10.1136/bcr-2017- \\
219501 \\
\hline
\end{tabular}

\section{DESCRIPTION}

Idiopathic unilateral facial nerve paralysis (Bell palsy) rarely occurs as a presenting symptom of childhood leukaemia, and published reports of Bell palsy as a symptom of leukaemic relapse are even fewer. ${ }^{1-3}$ These images show the MRI findings in this case of peripheral facial nerve palsy as an early presenting symptom of central nervous system (CNS) relapse.

This patient was diagnosed at 12 years of age with T-cell acute lymphoblastic leukaemia without CNS involvement. Five months into therapy, he developed vision loss in the left eye secondary to optic nerve leukaemic infiltration. Radiation therapy and intensification of his chemotherapy induced a durable radiographic response.

Sixteen months into therapy, the patient presented with a 1-day history of unilateral facial weakness. An MRI of the brain showed mild enhancement of portions of the right facial nerve, consistent with Bell palsy (figure 1). The patient received a 6-day course of prednisone and 1-week course of valacyclovir as empiric treatment.

One week later, the patient's facial nerve palsy had improved and he underwent a previously scheduled lumbar puncture with intrathecal chemotherapy. The CSF cell count showed only $1 \mathrm{WCC} /$ $\mu \mathrm{L}$ and $1 \mathrm{RBC} / \mu \mathrm{L}$, but the cerebrospinal fluid cytology was positive for lymphoblasts. He was diagnosed with CNS relapse. After 3 weeks of

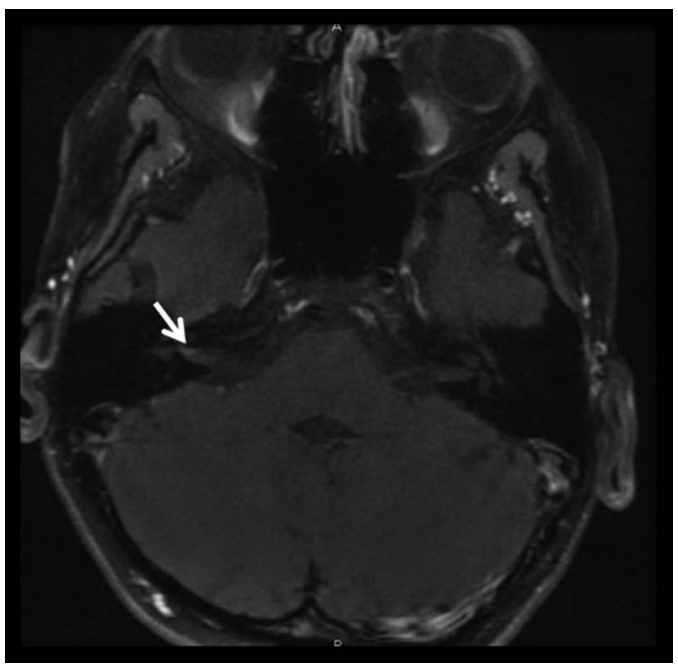

Figure 1 MRI postgadolinium T1-weighted axial sequence demonstrating enhancement of the proximal portion of the facial nerve (arrow).

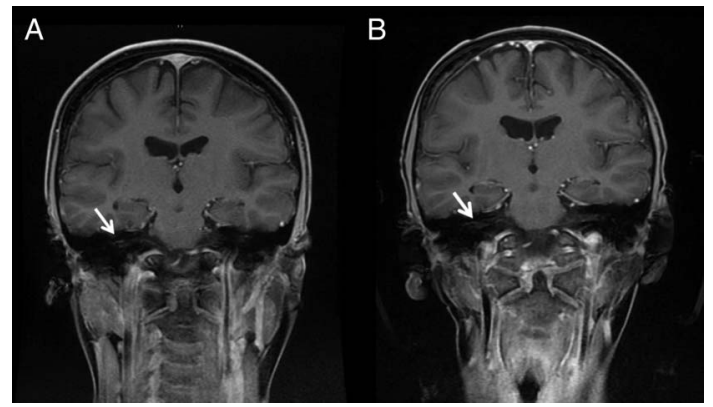

Figure 2 MRI postgadolinium coronal sequences demonstrating facial nerve enhancement (arrows) prior to chemotherapy $(A)$ and that subsequently resolved following chemotherapy (B).

reinduction chemotherapy, the facial palsy resolved completely, and 3 months later, an MRI showed resolution of the facial nerve enhancement (figure 2). He subsequently underwent a haematopoietic stem cell transplant.

\section{Learning points}

- Unilateral facial nerve palsy can be a rare presenting symptom of leukaemic relapse.

- MRI findings consistent with idiopathic Bell palsy cannot exclude the diagnosis of leukaemic relapse.

- Although most cases of Bell palsy are idiopathic, the development of a focal neurological deficit in a patient with known leukaemia warrants rigorous investigation and close surveillance for possible central nervous system relapse.

Competing interests None declared.

Patient consent Obtained.

Provenance and peer review Not commissioned; externally pee reviewed.

\section{REFERENCES}

1 Karimi M, Cohan N, Zareifar S, et al. Initial presentation of childhood leukaemia with facial palsy: three case reports. BMJ Case Rep 2009;2009: m.

2 Juhn YJ, Inoue S. Facial nerve palsy as an early manifestation of relapse in T-cell acute lymphoblastic leukemia. Ear Nose Throat J 1996;75:157-60.

3 Rhee D, Myssiorek D, Zahtz G, et al. Recurrent attacks of facial nerve palsy as the presenting sign of leukemic relapse. Laryngoscope 2002;112:235-7. 
Copyright 2017 BMJ Publishing Group. All rights reserved. For permission to reuse any of this content visit http://group.bmj.com/group/rights-licensing/permissions.

BMJ Case Report Fellows may re-use this article for personal use and teaching without any further permission.

Become a Fellow of BMJ Case Reports today and you can:

- Submit as many cases as you like

- Enjoy fast sympathetic peer review and rapid publication of accepted articles

- Access all the published articles

- Re-use any of the published material for personal use and teaching without further permission

For information on Institutional Fellowships contact consortiasales@bmjgroup.com

Visit casereports.bmj.com for more articles like this and to become a Fellow 